\title{
A STUDY OF THE DISTRIBUTION OF LAND ASSETS AND THE LEVEL OF PRODUCTIVITY IN INDIA: REGIONAL ANALYSIS
}

\author{
Suresh Deman*
}

\section{Section I}

The objective of this note is to conduct a regional study of inequalities in the ownership of land assets among the households and the productivity levels in rural communities in India. The renewed interest in India's problems of economic growth and distribution has been necessitated by the sequence of events that have taken place since the sixties. The study is based on a survey conducted by the Reserve Bank of India; entitled "All India Survey of Rural Credit and Investment, 1971-72." The household has been taken as unit of analysis following standard notion from Chayanov (1966), Heady (1964), Shanin (1971) and definition of assets close to Murray (1959). Assets as defined in the survey Table 4 includes all items owned by households in money value such as land, building, livestock, agricultural implements and machineries, durable household assets, dues receivable on loans advanced in cash and kind, shares in cooperative societies, banks etc., national saving certificates and the like, deposits in companies, banks, post offices and with individuals. Crops standing in the fields, currency notes and coins in hand and stocks of commodities, however, omitted from enumeration. Liabilities on the other hand include dues payable both in cash and kind.

There are twoapproaches to theory of regional development. The first approach is due to Pokshishevsky (1974) who holds the view that the regions are nothing but the natural regions which exist independent of our thinking. They cannot be created by social scientists. The second approach suggests that it is the researcher who creates regions on the basis of necessity and certain socio-economic indicators of development. These regions help in realizing the goal of a balanced regional development. The choice of criteria vary from researcher to researcher for identifying regions for their respective studies. However, regions being a neglected dimension, they have to be studied as a

\footnotetext{
*University of Connecticut-Hartford. I acknowledge the comments of Professors A. Ahmad, Amitab Kundu, Moonish Raza, G.S. Bhalla, K. P. Kalirajan, Harbans Singh Sidhu, and was benefited by the anonymous referees comments. Last but not the least my appreciation goes to my wife, Jennifer Mayo-Deman for typing the manuscript and Sushila Deman in computing. However, I am responsible for the omissions and errors.
}

theoretical and practical constituents of regional development. The first step in the regional development efforts is the precise delineation of areas according to the nature of their resources and disparities rather then on their administrative authorities. The analysis has to be carried down to a disaggregated level in view of very large size of administrative boundaries of the states and known geographical heterogeneity. The survey, divides the country into 66 agricultural regions. However, only 50 regions are covered by the present study. A few states like Gujarat, Jammu and Kashmir, and some Union Territories have been taken either as single homogenous regions or have been omitted completely due to non-availability of disagregated information on productivity.

India is predominately an agricultural country. This sector of the economy absorbs about 70 percent of our people, and it remains the largest contributor to GNP. Contribution originating from agricultural and allied activities works out to be 43.7 percent during 1973-74. The land assets are very important in the case study of economic development in general and development of agriculture in particular. The land assets share 66.16 percent of total assets in India and about 40 of income inequality is attributed to this particular factor. The ratio of livestock, buildings, household goods is $6.55,18$ and 46 percent respectively. The pattern of spatial distribution is not much different from the country as a whole. Deman (1974) gives a profile of India's economy.

\section{Section II}

There are broadly speaking two approaches in the literature to analyze the problem of inequalities. The first approach is predictive contemplative and the second is called the empirical. However, we confine our analysis on the latter and try to explore the connection between the distribution of land assets and the level of productivity. In this context, it will be appropriate to set out the extent of concentration in Indian agriculture vis-a-vis the productivity level, so as to get a broad idea about the order of their relative magnitude. There are several measures of inequality. For example, the range, the relative mean deviation, the variance, the coefficient of variation etc. There is no agreement among the economists over the "single best" measure of inequality. However, a measure that has been 
very widely used to represent the extent of inequality is the Gini-coefficient which may or may not be the best. Sen (1973) asserts:

"The idea of inequality is both very simple and complex. At one level, it is the simplest of all ideas and has moved people with an immediate appeal hardly matched by any other concept. At another level, however, it is an exceedingly complex notion which makes statements of inequality highly problematic."

The value of the Gini coefficient reduces with the transfer of income from the rich to the poor. But its sensitivity depends not on the size of the income (land assets) level but on the number of people (households) between them. It is obvious that if everyone's income is raised in the same proportion, its value remains invariant. In this paper inequalities in the distribution of land assets among the households across regions have been measured by the Gini Coefficeint. The formulae for calculating the Gini-coefficient is given by:

$$
G\left(Y_{i}\right)=1+1 / n-2 / n^{2} Z \sum_{i=1}^{n}(n+1-i) Y_{i}:
$$

where: i) $G\left(Y_{i}\right)$ is the Gini-coefficient

ii) $n$ is the number of frequency

iii) $\mathrm{Z}$ is the mean value for land assets

iv) $Y_{i}$ is the value in percentage terms of the variable (land assets).

The households and value of land assets have been taken in percentages, $(n+1-i)$ gives the weights and; $Y_{i}$ is the percentage value of land assets which goes from $\mathrm{i}=1,2,3, \ldots 15$. The frequency of the distribution is $\mathrm{N}=100$ (percent).

The productivity is defined as output per unit of land. The output of 19 crops in value terms has been divided by area to remove the scale effect. These crops are following: wheat, rice, jawar, bajra, maize, ragi, barley, gram, tur, groundnut, rapeseed and minis, scramon, linseed, gastorseed, sugarcane, cotton, jute and tobacco. The data of an economic variable like productivity may give misleading results, if the year in question happens for whatever reasons to be an abnormal year. Keeping in view the problem of seasonal constraint the data has been averaged over these consecutive years, i.e., 1970-71, 1971-72, and 1972-73.

All the 50 regions have been divided into four quartiles by way of arranging them in the descending order of their productivity levels. This will show spatial distribution of land assets over all the regions by the Gini-coefficients and at the same time the productivity levels. Similarly, the Gini coefficients have been shown separately to indicate the concentration of land assets.

\section{Section III}

To show region-wise distribution of the Gini coefficients and productivity levels, both have been ranked in order of their descending values. The corresponding rank value has been assigned to the respective regions. All values of the Gini coefficients and productivity have been divided into four quartiles. The respective quartile has been placed before the corresponding region. From Table 1 , it is clear that $13,11,14$ and 12 regions fall in I, II, III and IV quartile respectively. Table 1 (a) and (b) also show the serial numbers of the regions lying in four quartiles of different size class. Ranks in serial numbers of the above quartiles are also shown in descending order of the Gini coefficients as well as productivity in the above mentioned tables.

The highest value of the Gini-coefficient was found for the Coastal Ghats of Karnataka with 0.6511 value for the Gini coefficient. If we look at this region from the point of view of level of productivity then it stands in the category of high productivity quartile, i.e., I quartile, but with rank 7 in the descending order of productivity.

The first quartile having highest value of the Gini coefficient ranging from 0.6511 to 0.4829 includes the following regions in the descending order of their value. Jammu and Kashmir, Southern Punjab, Northern Punjab, Inland Tamil Nadu, Coastal Southem Tamil Nadu, Eastern Plains of West Bengal, Coastal Northern Tamil Nadu, Inland Central Maharashtra, Eastem Haryana, Coastal Andhra, Inland Western Madhya Pradesh, Central Plains of West Bengal, Himalayan West Bengal.

Twelve regions belong to the fourth quartile and the value for the Gini-coefficients ranges from 0.3566 to 0.1101 . There are three regions in this category having most equitable distribution of land assets; two regions belong to Rajasthan and one to Maharashtra.

The regions with most equitable distribution of landholding are North-East Rajasthan, Inland Northern Maharashtra and Southern Rajasthan. These regions belonged to IV quartile of very low value for the Ginicoefficient and the level of productivity. But this in no way reflects any proximity towards a socialistic pattern of development. In Southern Rajasthan, there is hardly any irrigation facility available and therefore, most of the land is desert; hence it is unproductive.

There are a few regions where the concentration of the land assets is very low but they show very high productivity level. These regions are following: Southem Kerala, Assam Hills and Northem Kerla. Because of the hilly regions in Assam, the importance of the land is not very vital there. The land is therefore, equitably distributed. Whereas in Kerla on account of the very strong trade 
Table 1(a)

Regional Structure of the Concentration of Land Assets

\begin{tabular}{|c|c|c|c|c|}
\hline Quartile & $\begin{array}{l}\text { Number of } \\
\text { Regions }\end{array}$ & Size Class & $\begin{array}{l}\text { Agricultural Regions in } \\
\text { order of (Serial Number) }\end{array}$ & $\begin{array}{c}\text { Ranks of Quartiles in descending } \\
\text { order of their Gini-coefficients } \\
\text { (Serial Number) }\end{array}$ \\
\hline I & 13 & $0.6511-0.4829$ & $\begin{array}{c}01,10,14,22,2733,34 \\
39,40,41,47,48,49\end{array}$ & \multirow{5}{*}{$\begin{array}{c}14,34,33,41,40,48,39 \\
27,10,01,22,49,47 \\
38,28,30,35,09,11,08 \\
43,14,42,04 \\
50,29,36,31,17,32,44,03,25 \\
02,07,21,23,16 \\
41,36,26,06,20,18 \\
24,12,13,05,19,37\end{array}$} \\
\hline II & 11 & $0.4829-0.4245$ & $\begin{array}{c}04,08,09,11,14,28 \\
30,35,38,42,43\end{array}$ & \\
\hline III & 14 & $0.4245-0.3566$ & $\begin{array}{c}02,03,07,16,17,21 \\
23,25,29,41,32,44,46,50\end{array}$ & \\
\hline IV & 12 & $0.3566-0.1101$ & $\begin{array}{c}05,06,12,13,18,19,20 \\
24,26,36,45\end{array}$ & \\
\hline \multicolumn{4}{|c|}{$\begin{array}{l}\text { Table 1(b) } \\
\text { Regional Structure of the Level of Productivity }\end{array}$} & \\
\hline Quartile & $\begin{array}{l}\text { Number of } \\
\text { Regions }\end{array}$ & Size Class & $\begin{array}{l}\text { Agricultural Regions in } \\
\text { order of (Serial Number) }\end{array}$ & $\begin{array}{c}\text { Ranks of Quartiles in descending } \\
\text { order of their Gini-coefficients } \\
\text { (Serial Number) }\end{array}$ \\
\hline I & 13 & $2030-1320$ & $\begin{array}{c}01,05,14,15,16,18,19 \\
33,34,40,41,42,50\end{array}$ & $\begin{array}{c}40,19,41,33,18,34,14 \\
15,42,05,01,50,16\end{array}$ \\
\hline II & 11 & $1390-1029$ & $\begin{array}{c}03,08,09,10,13,30 \\
43,44,45,48,49\end{array}$ & $\begin{array}{c}49,10,44,45,48,09,13 \\
08,30,43,03,21\end{array}$ \\
\hline III & 14 & $1029-711$ & $\begin{array}{c}04,06,07,11,12,17 \\
20,21,24,31,32,38,46,47\end{array}$ & $\begin{array}{l}06,04,32,31,12,46,11 \\
20,07,24,47,21,17,38\end{array}$ \\
\hline IV & 12 & $711-225$ & $\begin{array}{c}02,22,23,25,26,27,28 \\
29,35,36,37,39\end{array}$ & $\begin{array}{l}39,37,29,02,25,23 \\
22,26,28,27,36,35\end{array}$ \\
\hline
\end{tabular}

union movement of agricultural workers and peasants, it was possible to have an equitable distribution of land assets.

Similarly, in Kashmir land ceiling laws were introduced for the first time in India and a major part of the surplus land was distributed. Precisely for this reason there is a low concentration of land assets. Kashmir also falls in the IV quartile of the Gini coefficients.

The highest level of productivity was recorded in the Coastal Southern Tamil Nadu. The other regions in the descending order of productivity are as follows: Coastal Southern Tamil Nadu, Southern Kerla, Inland Tamil Nadu, Northern Punjab, Northern Kerla, Southern Punjab, Coastal Ghats of Karnataka, Inland Eastern Ghats of Karnataka, Himalayan Utter Pradesh, Assam-Hills, Coastal Andhra, Western Plains of West Bengal. Inland Southem Ghats of Karnataka. The level of productivity lies between 2030 and 1390 in the above thirteen regions. Frankel (1971) pointed out that a high level of productivity has been recorded in these regions because of the high fertility of land, the extensions as well as an increase in the availability of irrigation facilities, means of irrigation and a break through due to implementation of new technology during the period of the Green Revolution.

There were twelve regions in the range (710 to 225) of level of productivity. Northern and Western Rajasthan have very low level of productivity viz., 225 for each. The other regions of this category of lowest productivity, in the descending order are as follows:

Coastal Northern Tamil Nadu, Southem Rajasthan, Eastern Maharashtra, Inland Northern Andhra, Inland Western Maharashtra, Western Madhya Pradesh, Inland Western Madhya Pradesh, Inland Northern Maharashtra, Inland Eastern Maharashtra, Inland Coastal Maharashtra, North Eastern Rajasthan and Western Rajasthan.

Thus, we see that three regions of Rajasthan, four regions of Maharashtra, and tworegions of Madhya Pradesh, out of four, five and five regions of respective states fall in 
the fourth quartile of low-level of productivity. The desert land and adverse conditions of soil have placed Rajasthan in the lowest level of productivity hierarchy. The Southem Eastern Rajasthan shows a little high level of productivity among four regions of Rajasthan due to the extension of irrigation facilities as well as implementation of new technology in this area.

There are twenty five regions of the 50 agricultural regions of the study in India which fall in the intermediate category where concentration of land assets and productivity are neither very high nor it is very low. The range for this is 0.4829 to 0.3566 and 1390 to 711 respectively. These are the medium-low quartile, i.e., II and III quartiles in Table 1 (a) and (b).

If we take into consideration common regions belonging to I, II, III and IV quartiles from the viewpoint of level of productivity and concentration of land-assets then there were $6,4,6$, and 3 regions which fall in quartiles, mentioned in the above sequence.

Six common regions of the I quartile in the descending order of their values of the Gini-coefficients are namely, Coastal-Ghats of Karnataka, Southern Punjab, Northern Punjab, Inland Tamil Nadu, Coastal Southern Tamil Nadu, Coastal Andhra. But in order of descending values of productivity levels they are put in the following sequence: the Coastal Southern Tamil Nadu, Inland Tamil Nadu, Northern Punjab, Southern Punjab, Coastal Ghats of Karnataka and Coastal Andhra. Except Northern Punjab and Coastal Andhra the order of other regions has changed completely.

In the II quartile, fall only four common regions in the descending order of the Gini-coefficients namely, Central Orissa, Gujarat, Central Bihar and Western Utter Pradesh and the order is changed when we put them in the descending order of their level of productivity. Except Western Utter Pradesh, the order of other common regions has become as follows: Gujarat, Central Bihar, Central Orissa and Westem Uttar Pradesh.

The III quartile includes six common regions in the descending order of their Gini-coefficients namely, Southern Uttar Pradesh, Southern Orissa, Inland Northern Ghats of Karnataka, Northern Orissa, Northern Bihar and Inland Eastern Madhya Pradesh. Except the Southern Orissa the ranks of common regions have changed when they were arranged in the descending order of their productivity levels. The sequence has become as follows: Northern Orissa, Southern Orissa, Southern Uttar Pradesh, Northern Bihar, Inland Eastern Madhya Pradesh, Inland Northern Ghats of Karnataka.

Lastly, the IV quartile includes three common regions namely, Northeast Rajasthan, Inland Northern Maharashtra and Southern Rajasthan, in the above mentioned hierarchy. The ranking has changed in the follow- ing manner when they were put in the descending order of productivity level: Southern Rajasthan, Northeastern Rajasthan, and Inland Northern Maharashtra.

\section{Section IV}

In view of the above analysis of the regional structure of India's agricultural regions from both the angles, the productivity and concentration to quote Raj (1985) "the socalled revolution" has failed to raise the overall rate of growth of agriculture output above the level achieved in the 15 years prior to 1965 . The serious constraints on the productivity are the availability of readily cultivable land and either shortage or sharp variability of the supplies of water. These constraints can be overcome in the variety of ways but not overnight.

Thus, we draw the conclusion that the exaggerated notion regarding achievements and overly optimistic assessment of the future possibilities born out of the Green Revolution and the twin objectives set forth before the nation in our five year plans namely, the removal of poverty and reduction of inequalities, combining economic growth with social justice are yet to be fulfilled. Our findings about the socio-economic fall out of Green Revolution is further supported by a number of recent studies, for example, Rao (1975), Shah (1976), Chaudhury (1978), andRudra(1982). Julkaand Soni (1988) concluded that widespread disparities of incomes in the countryside have their foundation in the skewed distribution of productive resources and land assets. We suggest that steps should be taken in the direction of effective institutional changes leading to serious land reform, so that the Great dream of Garibi Hatao (removal of poverty) can be fulfilled and the fruits of the socio-economic development can be distributed equally among the rural masses.

\section{References}

Chaudhuri, Pramit., "Pattern of Industrial Growth," The American Economic Review, Vol. L, No. 4, 1988.

Chayanov, A. V., in The Theory of Peasant Economy, Ed. by Daniel Thoner et al., Richard D. Irwin, Inc., Homewood, Illinois, 1966.

Deman, S., "Profile of India's Economy," Economic Affairs, 1974.

Frankel, F. R., India's Green Revolution: Economic Gains and Political Costs, Princeton University Press, 1971.

Heady, E. O., Economics Agriculture Production and Resources Use, Princeton- Hall of India, New Delhi, 1964.

Julka, A. C. and Soni, R. N., "Inequalities of Income, Land Ownership and Associated Assets Among Cultivating Households of Punjab: An Experience in Determinant Decomposition," Indian Joumal of Agriculture Economics, Vol. 
43, No. 2, 1988.

Murray, R. H. "The Concept of Income-Economic and Legal Aspects," in Readings in the Economics of Taxation. American Economic Association, George Allen and Unwin Ltd., London, 1959.

Pokshishevsky, V. V. (1974), Progress in Geography, Moscow: Progress Publishers, Vol. VII, Ch. I.

Raj, K. N. (1985), Essays on the Commercialization of Indian Agriculture, Oxford University Press, New Delhi, India.

Rao, C. H. H., Technical Change and Distribution of Gains in Indian Agriculture, The Mac Millan Company of India Lid. Delhi. 1975.

Rudra, Ashok, Indian Agriculture Economics: Myths and
Realities, Allied Publisher Pvt. Ltd., Delhi, 1982.

Sen, A. K. (1973), On Economic Inequality, Oxford University Press, New Delhi.

Shah, C. H., "Growth and Inequality in Agriculture," Indian Journal of Agriculture Economics, Vol. XXXI, No. 4, 1976.

Shanin, T., The Awkward Class: Political Sociology of Peasantry in a Developins Society: Russia 1910-1925. Clarendon Press, Oxford, 1972.

The Reserve Bank of India: "All India Survey of Rural Credit and Investment, 1971-72" (Table 4), Vol. I and II.

The Reserve Bank of India, Bulletin, Currency and Finance, 1974-75. 